\title{
On the Fertilization of Peronospora parasitica.
}

\author{
BY
}

HAROLD WAGER.

\section{With Plate XVI.}

SINCE the classical researches of De Bary upon the $D$ phenomena of fertilization in the Peronosporeae ${ }^{1}$, the subject has been studied by Marshall Ward ${ }^{2}$, Fisch ${ }^{3}$, Chmielewsky ${ }^{4}$, Istvanff ${ }^{5}$, Dangeard ${ }^{6}$, Berlese ${ }^{7}$, Stevens ${ }^{8}$, and myself.

The investigations of De Bary and Marshall Ward definitely established the fact that certain genera of the Peronosporeae exhibited some of the phenomena of fertilization in the fusion of protoplasmic masses derived from male and female cells.

${ }^{1}$ See Comp. Morph. \&c., of Fungi, Eng. Ed.

${ }^{2}$ Observations on the genus Pythium. Q. J. M. S., xxiii, 1893.

${ }^{3}$ Ueber das Verhalten der Zellkerne in fusionierenden Pilzzellen. See Bot. Cent. xxiv, p. 22 I.

4 Zur Frage über die Copulation der Kerne beim Geschlechtsprocess der Pilze. See Bot. Cent. xxxviii, p. 689.

${ }^{5}$ Ueber die Rolle der Zellkerne bei der Entwicklung der Pilze. Ber. d. deut. Bot. Gesell. xiii, 1895, p. 456 .

- Recherches sur la Reproduction sexuelle des Champignons. Le Botaniste, I 894 , p. 22 I.

7 Ueber die Befruchtung und Entwickelung der Oosphäre bei den Peronosporeen。 Jahr. f. wiss. Bot. xxxi, p. I 59 .

${ }^{8}$ The compound Oosphere of Albugo Bliti. Bot. Gaz. xxviii, 1899.

[Annals of Botany, Vol. XIV. No. LIV. June, 1900.] 
In Pythium, for example, it was shown that nearly the whole of the protoplasm in the antheridium passed over into the oosphere through the fertilizing tube. In Phytophthora a very minute quantity only was seen to pass over into the oosphere, and in the other genera the passage of protoplasm from the male to the female organ could not be seen.

At that time nothing was known of the part taken by the nuclei in this process. The presence of nuclei in the cells of the Peronosporeae had been announced by Schmitz in $1879^{1}$, but their behaviour in the process of fertilization was first of all studied by Fisch in $1885^{2}$. He investigated the genera Pythium and Cystopus, and came to the conclusion that, in Pythium, the nuclei of the oogonium fuse together to form a single female pro-nucleus, that the antheridium contains a single nucleus probably also due to the fusion of several nuclei; and that in the process of fertilization the nucleus of the antheridium passes over into the oosphere and becomes fused with the female nucleus to form the single nucleus of the oospore.

These observations on Pythium have never been confirmed or refuted; and in the light of recent investigations it is very desirable that this genus should be thoroughly studied. This is the more important, as the imperfect observations made by Fisch upon fertilization in Cystopus ${ }^{3}$, which, he stated, presented, so far as could be seen, phenomena of fertilization similar to those observed in Pythium, have since been shown by more than one observer to be incorrect. His observations on the multinucleate character of the oogonium and antheridium in Cystopus have however been confirmed by all observers except Chmielewsky ${ }^{4}$, who described the oogonium and antheridium of $C$. candidus as uninucleate structures, and states that Fisch must have mistaken the knots in the protoplasmic network for nuclei.

1 Untersuchungen über die Zellkerne der Thallophyten. Verhandlungen des naturhistorischen Vereins der preussischen Rheinlande und Westfalens, Bd. xxxvi, p. 345 .

${ }^{2}$ loc. cit. ${ }^{3}$ loc: cit. 


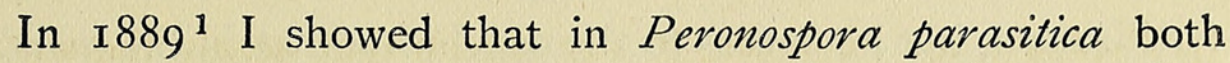
oogonium and antheridium are multinucleate; that previous to the differentiation of the oosphere the nuclei of both these organs undergo mitosis; that in the separation of the oosphere from the periplasm the majority of the nuclei of the oogonium pass into the periplasmic layer, and that finally the oosphere when ready for fertilization contains only one nucleus.

The exact details of the fertilization were not investigated, but the following conclusion was arrived at from a consideration of the facts observed: "The passage of a nucleus from the antheridium into the oosphere has not been directly observed, but it is probable that fertilization does take place, as two nuclei have been seen in the oosphere at about the time when a nucleus or nuclei from the antheridium appear to pass over into the fertilizing tube.'

Istvanff ${ }^{2}$, in I 889 , described the oogonia and antheridia of Cystopus Portulacae as multinucleate, and referred to the process of fertilization as consisting probably in the fusion of the nuclei of the two sexual organs. 'Die Befruchtung erfolgt auch hier höchst wahrscheinlich nur durch die Vermischung der Zellkerne beiderlei Sexualorgane.'

In I894 Dangeard ${ }^{3}$ made some observations on Pythium monospermum Prings. and $P$. proliferum De Bary, in which he showed that the antheridia and oogonia are multinucleate. $\mathrm{He}$ also pointed out that a central oleaginous globule appears in the oogonium at a certain stage, and that this was probably mistaken by Fisch for a nucleus and led him to the conclusion that all the nuclei of the oogonium fused together to form a single sexual nucleus.

Dangeard also found that the antheridia and oogonia are multinucleate in C. candidus, C. cubicus, Plasmopara nivea, and $P$. densa. He was unable to observe any details of

1 Wager, On the Nuclei of Peronospora parasitica, \&c., Ann. of Bot., vol. iv, p. 127.

${ }^{2}$ A penészek sejtmagávról (De fungorum nucleis). Magyar Növénytani Lapok, xiii, I889, pp. 33-46. See Ueber die Rolle der Zellkerne bei der Entwickelung der Pilze, Ber. d. deut. Bot. Gesell., Nov. I 895 , p. 457 .

3 loc. cit. 
fertilization, but he comes to the conclusion that in C.candidus some of the nuclei remain in the periplasm and contribute to the formation of the exospore, the others remain in the oosphere, and are there probably joined by the nuclei from the antheridium ${ }^{1}$. In Plasmopara densa he made the interesting observation that when the protoplasm concentrates towards the centre of the oogonium for the purpose of forming the oosphere, two small nuclei are visible at the centre quite close together; the other nuclei are found in the periplasm. He was, however, unable to say whether these two nuclei fuse together or not.

The question of fertilization in the Peronosporeae remained at this stage until the appearance of my paper on Cystopus candidus in $1896^{2}$, in which I described in detail the differentiation of the oosphere, and the fertilization and maturation of the zygote. Previous to fertilization, all the nuclei, both of the antheridium and oogonium, undergo mitosis. One of these nuclei becomes separated from the others in the oogonium to form the nucleus of the oosphere, and this then fuses with a single nucleus from the antheridium, which passes into the oosphere through the fertilizing tube, to form the egg or zygote nucleus. This nucleus immediately divides, and by subsequent divisions thirty-two nuclei are formed, so that the ripe zygote is multinucleate.

These results were confirmed by Berlese ${ }^{3}$ on Cystopus Portulacae, and he further extended them to various species of Peronospora, P. Ficariae, P. Alsinearum, and P. effusa. His observations confirm my own in every important and essential detail, except as to the condition of the nuclei in the actual fusion. In $C$. candidus I pointed out that the fusion takes place in the resting stage of the nuclei. In C. Portulacae and Peronospora Ficariae, Berlese's figures indicate the same thing; but in his figures of $P$. Alsinearum

\footnotetext{
1 loc. cit., p. $\mathbf{2} 28$.

${ }^{2}$ On the Structure and Reproduction of Cystopus candidus Lev., Ann. of Bot. x, 1896.

loc. cit.
} 
and $P$. effusa he shows a state of fusion in which the fusing nuclei are similar to those in Ascaris, in which the fusion takes place in the chromosome stage, and the chromosomes are visible before fusion; and he refers generally to the process of fertilization in the following words as if it referred to the whole group: 'Auch die Chromosomen werden gut sichtbar, und ich konnte auch im Spermakern I2-16 derselben nachweisen; die Kernmembran verschwindet allmählich und es beginnt die Verschmelzung der beiden Kerne.... Es geht mit Sicherheit aus meinen Untersuchungen hervor, dass der embryonale Kern aus einer Zahl von Chromosomen zusammengesetzt ist, die um die Hälfte grösser ist als die Zahl der Chromosomen, welche in einem jeden der beiden Geschlechtskerne, die ihn zusammensetzen, nachweisbar ist, und dass dieselben vor der Befruchtung gar keine Reduction zeigen.'

With this exception, however, Berlese and I are in agreement as to the essential facts of fertilization in Cystopus, and it now remained for me to determine whether my former observations on $P$. parasitica ${ }^{1}$ - that the formation of the female or oosphere-nucleus takes place by the fusion of two or more periplasmic nuclei, and that the ripe oospore is uninucleate-were correct, or whether the facts are in accord with the more recent observations of Berlese on Peronospora, and especially with his statement that the ripe oospore of $P$. parasitica is multinucleate ${ }^{2}$. I found on reinvestigation that the process of fertilization is similar in its essential features to that which takes place in $C$. candidus, but that, unlike all the other species of Peronospora and Cystopus which have so far been examined, the ripe zygote is uninucleate.

Stevens ${ }^{3}$ has recently published an account of the fertilization in Cystopus (Albugo) Bliti, which differs entirely in its essential details from that described by Berlese and myself for other members of the group. The oogonium and antheridium

\footnotetext{
1 Annals of Botany, vol. iv, Nov, 1889.

${ }^{2}$ Berlese, loc. cit. p. I8I.

3 loc. cit.
} 
are multinucleate and agree in their general structure with those of the species already described. The protoplasm becomes differentiated into an oosphere and periplasm. All the nuclei pass into the periplasm and there undergo mitosis. The oogonium contains about 250 nuclei, the antheridium about 35 , which is a larger number than occurs either in C. Portulacae or C. candidus. So far the observations are, with differences in details, generally in accord with those made by previous observers; but he now goes on to point out, after describing in detail the process of nuclear division in the oogonium, that 'those dividing nuclei that lie tangential to or wholly outside of the boundary line between the ooplasm and periplasm leave their daughter-nuclei in the periplasm. Each of the spindles which cross the line (boundary between oosphere and periplasm) gives one daughter-nucleus to the oosphere and the other to the periplasm, and the line of differentiation is sharply defined and unmistakable.' 'As a result of the division a large number of nuclei pass into the ooplasm, thus producing a multinucleate cell (oosphere) containing by actual count an average of forty-five to fifty-five nuclei.' Thus 'the mature oosphere contains many female nuclei, and fertilization is effected by the discharge of many male nuclei from the antheridial tube and their subsequent fusion with the female nuclei in pairs. An oospore results from this multiple sexual act with about one hundred fusion nuclei, which remain in the resting condition until germination.'

These observations are exceedingly interesting, as they indicate that the process of fertilization in the Peronosporeae is not necessarily the same for all genera or for all species even of the same genus. It becomes very important, therefore, that the process of fertilization in this group should be studied in as many forms as possible. Up to the present time four different methods of fertilization in the Peronosporeae have been described. One of these, described by Chmielewsky for Cystopus candidus, has been shown to be incorrect. The others still stand. These three methods are- 
I. Collective nuclear fusion as in Pythium (Fisch).

2. Binuclear fusion as in Cystopus candidus, C. Portulacae and species of Peronospora (Wager and Berlese).

3. Multiple nuclear fusion, in pairs, as in C. Bliti (Stevens).

It is probable that the method of fertilization described by Fisch for Pythium will be found to be untenable. The second type of nuclear fusion has been found to be the most frequent in the Peronosporeae, so far; and the third type must be regarded therefore, at present, as the anomalous one.

The observations on $P$. parasitica which follow show that this species comes definitely in the second group. As the general structure of the Fungus was described in a previous paper I shall confine myself here to a description of the sexual organs and the process of fertilization.

As in Cystopus, the nuclei of the young oogonium of Peronospora parasitica are irregular in shape and the outline of the oogonium, before it is cut off from the parent hypha, presents a somewhat crumpled appearance; the nuclei are often elongated in the direction of the flow of the protoplasm into the oogonium as in Cystopus candidus, and as Stevens has also shown to be the case in C. Bliti. As soon as the partition-wall separating the oogonium from the hypha is formed, the oogonium expands and becomes more or less spherical; the nuclei at the same time regain their spherical shape (Plate XVI, Fig. I).

The structure of the nuclei at this stage is simple. They possess a nuclear membrane and a granular network, but no nucleolus, or if a nucleolus is present it is very small and difficult to distinguish from the granules of the network. The structure of the nuclei of the antheridium is the same.

Soon after the delimitation of the oogonium the protoplasm exhibits a vacuolar structure; the antheridium becomes closely attached to the wall of the oogonium and, as I have shown is also the case in Cystopus, a granular mass of protoplasm appears just beneath the membrane of the oogonium at the place where the fertilizing tube will be formed. At this point the wall separating the oogonium from 
the antheridium becomes very thin and a slight hyaline protoplasmic papilla becomes formed which tends to push itself into the antheridium (Fig. I). The same structure occurs in C.candidus, but is more prominent, and in C. Bliti Stevens has shown that it is still more highly developed; for the protoplasm pushes itself actually into the antheridium and there forms a very conspicuous swollen papilla inside it ${ }^{1}$.

Whatever may be the exact explanation of this curious structure, it appears to be connected in some way with the perforation of the oogonial wall and the formation of the fertilizing tube. It is much less highly developed in C.candidus and $P$. parasitica than in $C$. Bliti. I have called it the receptive papilla, because it marks the place where the penetration of the fertilizing tube takes place. Stevens is inclined to give it a more important significance than this; but it appears to me to be distinctly homologous with the receptive spot of other ovum-cells and to perform a similar function. Such receptive spots or papillae are found in the oogonia of Vaucheria and Oedogonium, and are well marked differentiations in the protoplasm.

As soon as the oogonium is formed the nuclei begin to increase in size; the linin-network and chromatin-granules become more prominent and stain more deeply. The cytoplasm loses at the same time, to some extent, its power of taking up stains, and the vacuoles become larger and less numerous. Then a differentiation of the protoplasm into ooplasm and periplasm begins, and all the nuclei pass into the periplasm (Fig. 2). They here undergo mitosis. The two regions are distinctly marked off from one another, although as yet there is no partition-wall between them. The periplasm is a granular, homogeneous layer at the periphery of the oogonium. The ooplasm is a vacuolate spherical mass of cytoplasm in the centre (Figs. 2, 3, 4). The nuclei at this stage are often arranged in a single regular layer immediately around the periphery of the ooplasm ${ }^{2}$.

${ }^{1}$ loc. cit. p. ${ }_{54}$ (see Plate XIII, Figs. 47-54).

${ }^{2}$ See Fig. 8, Plate VI, Ann. of Bot., vol. iv, I889. 
The changes just described differ from those observed in Cystopus. In $C$. candidus the protoplasm first becomes separated into a peripheral vacuolar portion and a central denser protoplasm containing all the nuclei and smaller vacuoles. Then the central mass separates into a vacuolar ooplasm and a non-vacuolate granular layer of periplasm, into which all the nuclei pass. Stevens describes a somewhat similar phenomenon in $C$. Bliti ${ }^{1}$, where the protoplasm of the young oogonium is irregularly vacuolate. In the process of differentiation of the oosphere accumulations of denser protoplasm are found, separated from one another and the wall of the oogonium by vacuoles of varying sizes. These denser protoplasmic masses coalesce and the vacuoles become restricted to the periphery, so that we get, as in C.candidus, a central denser mass of protoplasm surrounded by a vacuolar layer. The nuclei pass to the periphery of the central mass, and then the periplasm becomes distinctly differentiated as a dense granular layer around and between the nuclei. The condition in which there is a distinct line of demarcation between periplasm and ooplasm, but no definite wall between the two, is called by Stevens 'the stage of zonation' (p. 157).

As the nuclei pass into the periplasm they undergo changes which lead to division. They increase in size and the chromatin-granules fuse together to form the chromosomes, deeply staining granules, which accumulate in the equatorial plane. A spindle is formed, the nuclear membrane disappears, and the chromosomes become divided into two groups which separate to become the daughter-nuclei. No nucleolus is visible during the mitosis and no definite centrosomes, although occasionally granules at the poles of the spindle were observed which might have been taken for such. The nuclear division described by Stevens in $C$. Bliti agrees in its essential details with this, except that the nucleolus persists until a late stage in the division and the nuclear membrane does not disappear so soon. The nuclei of the antheridium appear to divide simultaneously with those in the oogonium.

1 loc. cit. 
During the nuclear division the cytoplasm of the oosphere undergoes changes. The larger vacuoles disappear and smaller ones take their place; the central cytoplasmic mass becomes vacuolate; and, finally, the whole of the protoplasm of the oosphere exhibits a distinct foam-structure due to the large number of small vacuoles which now take the place of the larger ones, of which none, or only one or two, may remain (Figs. 5, 6, 7).

As this vacuolization is taking place a central homogeneous body makes its appearance (Figs. 2-7). This appears to be formed by the gradual condensation of a mass of granular cytoplasm in the centre or near the centre of the oosphere (Figs. 2, 3); and when it is completely formed it stains more deeply than the surrounding cytoplasm (Figs. 4, 5, 6). This structure has been known for some time, but it was first correctly described and its probable function indicated in my paper on $C$. candidus $^{1}$. It was, as I have previously pointed out, probably this structure which was described by Dangeard ${ }^{2}$ as an oil drop and by other observers as a nucleus. Swingle confirms my description of it, and suggests that it is a new organ or organoid of the cell ${ }^{3}$. In my original description of it I pointed out that shortly after its appearance one of the nuclei produced by division in the oogonium comes into close contact with it and gradually becomes more or less embedded in it; the fertilizing tube also grows directly towards and comes into contact with it. This indicates that it may in some way or other exert an attraction first upon the female nucleus, and secondly upon the fertilizing tube, thus helping to bring the sexual nuclei together. Stevens, who finds a similar structure in $C$. Bliti, C. Tragopogonis, and $C$. Portulacae, believes that we have here an organ of the oosphere which may be of the nature of a dynamic centre. He proposes to call it a coenocentrum. As I pointed out, however, in $C$. candidus, and as Stevens shows in C. Bliti, it is not a permanent organ of the cell. It disappears in $C$. can-

${ }^{1}$ loc. cit.

2 loc. cit.

${ }^{3}$ Two new Organs of the Plant Cell. See Bot. Gazette, 1898 , p. IIo. 
didus soon after fertilization, as Swingle has also shown ${ }^{1}$, and in $C$. Bliti it reaches its maximum development when the daughter-nuclei of the first mitosis pass into the oosphere, but disappears before fertilization takes place ${ }^{2}$. In $P$.parasitica, as in C. candidus, it attains its highest development at the time when fertilization is just about to take place (Fig. 6); after fertilization it begins to degenerate, and finally disappears (Figs. 8, 9). That it is not concerned actually in the fusion of the sexual nuclei, but only in bringing them together, is indicated by the fact that in $P$.parasitica, although it is present when the nuclei come together for the first time, it has completely disappeared before fusion takes place (Figs. 9-14). In C.candidus, where the nuclear fusion takes place immediately after the male nucleus enters the oosphere, the coenocentrum does not entirely disappear until the fusion is complete. All the evidence therefore before us, as to the function of this structure, indicates that it is functional in bringing the sexual nuclei together; and from the fact that in $P$. parasitica the female pro-nucleus becomes elongated in the direction of the coenocentrum, as it passes towards it through the oosphere (Fig. 4), and that the fertilizing tube may grow directly towards it (Fig. 7), it appears that it may exert an attractive force of some kind by which the sexual nuclei are brought into contact, and that as soon as this has been accomplished it begins to disappear.

As soon as this central body has made its appearance, one of the nuclei from the periplasmic layer comes into close contact with it (Figs. 4-7). This is the female pro-nucleus. In my former paper I stated that this nucleus was formed by the fusion of two nuclei, but this is not supported by my recent observations, and I suspect that I was misled by the coenocentrum, which at this stage looks very much like a nucleus, especially in badly stained specimens. This nucleus becomes elongated in the direction of the coenocentrum as it passes through the cytoplasm, and when it reaches the coenocentrum it is often spindle-shaped or fusiform (Fig. 4). Even

\footnotetext{
${ }^{1}$ Swingle, loc. cit.

${ }^{2}$ Stevens, loc. cit. p. $\mathbf{1 6 2}$.
} 
in the periplasm it is often elongated; and I have sometimes seen more than one nucleus in the periplasm elongated in the direction of the coenocentrum: but so far as I have been able to observe, only one nucleus actually comes into contact with it. The ooplasm at this stage is finely vacuolate and possesses in consequence a very distinct foam-structure (Fig. 5).

The fertilizing tube penetrates the oogonium at the place where the receptive papilla is formed. It forms at first a thin-walled spherical or oval sac in contact with the periplasm (Figs. 4, 5). It then penetrates the oosphere by means of a thin-walled tubular portion which is pushed out at its apex (Fig. 7). The fertilizing tube then presents a characteristic appearance, consisting of a thin-walled tubular portion in the oosphere and a slightly expanded, more or less spherical portion, in the periplasm. There are no nuclei in the tube when it is first formed, but before it has pushed itself into the oosphere, one nucleus from the antheridium passes into it, and as it penetrates the oosphere a second nucleus may pass into it (Fig. 7).

Just before it passes into the fertilizing tube, the antheridial nucleus changes its shape, becoming slightly elongated and often pointed at the anterior end (Fig. 4); this apparently enables it to pass more easily through the narrow opening which leads from the antheridium into the fertilizing tube.

When the apex of the fertilizing tube comes into the neighbourhood of the central mass, with which the female nucleus is in contact, it opens and the male nucleus passes through the aperture into the oosphere and comes into contact with the coenocentrum (Figs. 7,8). The male nucleus is slightly smaller than the female nucleus and stains differently in the carmine-nigrosin stain; the male nucleus is stained red, the female nucleus blue. They come into close contact, but do not fuse at once; they gradually increase in size, the male more rapidly than the female, until they are approximately equal, and then separate to opposite sides of the 


\section{of Peronospora parasitica.}

cell (Fig. 9). In this position they become more deeply stainable, and consequently more conspicuous. Their structure exhibits a granular network, with deeply stained granules, and in the later stages a nucleolus can be made out.

Meanwhile the wall of the oospore, which was beginning to form just at the time of fertilization, has been increasing in thickness and forms now a very definite membrane, surrounded by the periplasm and the rest of the oogonial nuclei. The protoplasmic contents lose their fine vacuolate structure. The vacuoles decrease in number and increase in size. They mark the position of the large oil-drops which are seen in the living oospore. The cytoplasm at this stage stains less intensely than before, but the two nuclei, which are now very conspicuous objects in the cell, stain more deeply, having apparently taken up the stainable substances of the cytoplasm.

The fusion of the two nuclei now takes place (Figs. 10-15). They gradually approach again and come into close contact. The wall between them breaks down and the contents of the two nuclei fuse together. First they are dumb-bell shaped, then oval, and finally, when the fusion is complete, spherical (Fig. I6). The nucleoli remain distinct until the fusion is nearly completed, they then fuse together to form a single conspicuous nucleolus which stains deeply. The fusion definitely takes place in the resting stage of the nuclei; there is no indication whatever of chromosomes, as figured by Berlese in $P$. Alsinearum and $P$. effusa.

The retarded nuclear fusion just described is not uncommon. It may occur in the zygotes of Spirogyra, Cosmarium, Closterium, Basidiobolus, and Polyphagus, and, in some cases, may even not take place until germination has commenced.

In the Peronosporeae we have the two types of fusion. In C. candidus, as I have shown, the nuclei fuse at once, immediately after the entry of the male nucleus into the oosphere, and the same thing also occurs in $C$. Portulacae, $P$. Ficariae, $P$. Alsinearum and $P$. effusa according to Berlese. P. parasitica is at present the only member of the group with retarded 
nuclear fusion; and in this species it is delayed until the thick zygote-membrane has been partly formed.

At the time the fusion takes place the protoplasm of the oospore contains numerous oil-drops. These gradually fuse together to form a large central oil-globule of weak refringent power. The protoplasm fills the space between the oil-drop and the membrane. It is a finely granular substance and contains, as De Bary ${ }^{1}$ pointed out, 'a round or elongated and perfectly pellucid spot' close to the membrane on one side of the spore. De Bary surmised that this might be the nucleus, and this turns out to be correct. The ripe oospore of $P$. parasitica is uninucleate; the nucleus is found in the position indicated by De Bary and is clearly visible in the living condition. In all the other species of Peronospora which have been examined the ripe zygote is multinucleate, and in Cystopus, so far as we know at present, the ripe oospores of all species are multinucleate. Whether the zygote of $P$. parasitica becomes multinucleate just before germination takes place I do not know, as I have not yet been able to get them to germinate.

The periplasm and periplasmic nuclei remain visible for some time but ultimately become transformed into the exosporium, which is laid down on the surface of the endosporium as a coarse network (Fig. 17). The wall of the oogonium persists, and as the oospore ripens it becomes much thickened and serves as an additional protective layer.

The phenomena of fertilization in $P$. parasitica thus described conform, in their essential characteristics, with those observed in the higher plants and animals, so far as the actual fusion of nuclei is concerned; and it resembles in a striking manner the fusion of nuclei in Coleochaete pulvinata described by Oltmanns ${ }^{2}$. Unfortunately however it has not been possible to arrive at any definite conclusions as to the question of chromosome-reduction, but it appears to me, from

${ }^{1}$ Fungi, Eng. Edit., p. I35.

${ }^{2}$ Die Entwickelung der Sexualorgane bei Coleochaete pulvinata. Flora, vol. $\operatorname{lxxxv}, 1898$. 
the few observations which I have been able to make, that a reduction in the number of chromosomes takes place during the mitosis in the oogonium and probably in the antheridium. Berlese states that in C. Portulacae the reduction takes place on the germination of the zygote; but Stevens says that in C. Bliti 'there is some evidence that makes it appear that there is a reduction in the number of chromosomes during the first mitosis' in the oogonium.

It is evident that further investigation is necessary before any definite statement can be made as to the reduction of chromosomes in the Peronosporeae.

\section{SumMARY AND CONCLUSIONS.}

I. The protoplasm of the oogonium becomes differentiated into a central vacuolate ooplasm and a granular homogeneous periplasm.

2. Immediately before this takes place a receptive papilla is formed on the oogonium at the place where the antheridium is in contact with it. At this spot the wall of the oogonium becomes very thin, and it is here that the fertilizing tube of the antheridium penetrates the oogonium.

3. The nuclei of the oogonium and antheridium undergo mitosis previous to fertilization.

4. Soon after the delimitation of the oosphere, a dense granular mass appears in the centre of it, which becomes converted into a homogeneous, ill-defined body, which stains more deeply than the surrounding cytoplasm. This central body appears to play some part in bringing the sexual nuclei together.

5. A single nucleus from the periplasm of the oosphere travels towards the central body and comes into close contact with it. The fertilizing tube of the antheridium also grows towards it and discharges a single nucleus, which comes into close contact with the female nucleus.

6. The sexual nuclei do not fuse at once, but remain apart for some time and increase in size, probably at the expense 
of nutrient material in the cytoplasm. The male nucleus is at first slightly smaller than the female, but they soon become approximately of the same size and exhibit the same structure.

7. The fusion takes place while the nuclei are in the resting stage and not until the zygote is nearly ripe.

8. Before fusion takes place the central body disappears.

9. The ripe zygote is uninucleate. It contains a central large pale oil-globule and a peripheral layer of granular protoplasm, in which the nucleus is placed. The nucleus can be seen in the living condition as a pellucid spot in the protoplasm.

I0. Of all the nuclei in the oogonium only one is set apart for the purpose of reproduction; the others remain in the periplasm and are used up to form the protective layer or layers of the oospore.

II. No difference is observable between the sexual nucleus and those that remain in the periplasm. They are the same size, have the same structure, and stain in a similar manner. It is probable therefore that all the nuclei of the oogonium are potentially sexual. In $C$. Bliti, as shown by Stevens, it appears to be a mere accident that determines which of the nuclei in the periplasm shall give off daughter-nuclei to the oosphere.

12. On comparing the various methods of fertilization and oospore-formation in the Peronosporeae, we can, so far, distinguish three types. (I) Uninucleate oosphere, binuclear fusion and uninucleate oospore ( $P$.parasitica). (2) Uninucleate oosphere, binuclear fusion and multinucleate oospore $(C$. candidus, C. Portulacae and P. Ficariae. (3) Multinucleate oosphere, multinuclear fusion in pairs and multinucleate oospore (C. Bliti). Whether Pythium will have to be regarded as a fourth type can only be decided by further investigation. 


\title{
EXPLANATION OF FIGURES IN PLATE XVI.
}

\author{
Illustrating Mr. Harold Wager's paper on Peronospora parasitica.
}

All the figures have been drawn with the aid of the camera lucida, and the apochromatic $2.0 \mathrm{~m} . \mathrm{m} .$, I.40 apert., of Zeiss, with ocular 8 ( $\times$ I000). The details were filled in with the aid of a magnification of 1500 (ocular I2), or $225^{\circ}$ (ocular I8).

Fig. I. Young oogonium with antheridium and receptive papilla.

Fig. 2. Nuclei in the periplasm in process of division. The antheridium has put out a fertilizing tube, and the central body is just beginning to form in the ooplasm.

Fig. 3. Mitosis just completed; the central body is slightly more prominent.

Fig. 4. The central body is now very distinct, and a single nucleus from the periplasm is in contact with it. A nucleus is just about to pass from the antheridium into the fertilizing tube.

Fig. 5. The cytoplasm of the oosphere is finely vacuolate. A nucleus is seen in the fertilizing tube. There is now a distinct line of demarcation between the ooplasm and periplasm.

Fig. 6. A stage slightly later than Fig. 5, showing the first indication of the wall of the oosphere.

Fig. 7. Fertilizing tube nearly in contact with the female nucleus. It appears as if about to open at the apex. Two nuclei are to be seen in it.

Fig. 8. The sexual nuclei shortly after the entry of the male nucleus into the oosphere. The central body is already not so prominent and is beginning to disappear.

Fig. 9. Later stage: the nuclei are at some distance from one another. The wall of the oosphere is now very prominent.

Fig. 10. The sexual nuclei at a later stage. The apparent difference in size is due to the fact that one nucleus is seen from the end, the other from the side.

Fig. II. The sexual nuclei in close contact. They are just beginning to fuse.

Fig. I2. The sexual nuclei in early stage of fusion. The cytoplasm contains large vacuoles.

Fig. 13. Later stage of fusion.

Fig. I4. Nuclei completely fused to form a single oval nucleus. The nucleoli are still visible.

Fig. I5. Fusion-nucleus, showing a distinct network and a single nucleolus.

Fig. I6. Nearly ripe oospore with single nucleus.

Fig. 17. Nearly ripe oospore with oogonial wall, showing how the periplasm is deposited on the wall of the oospore to form the exosporial layer. 

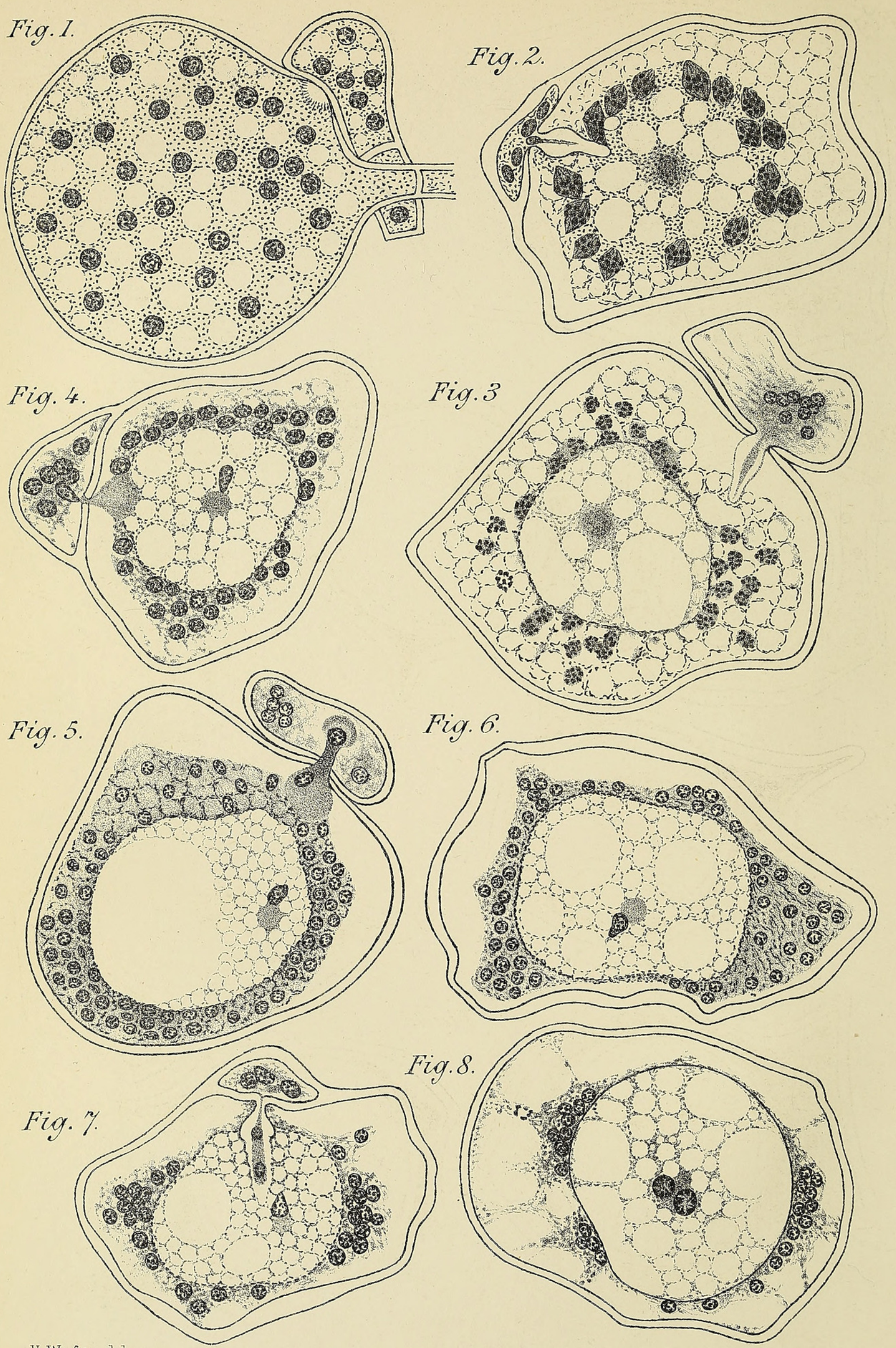

H.Waser del.

WAGER. - ON PERONOSPORA PARASITICA. 


\section{$2 \mathrm{BHL}$ Biodiversity Heritage Library}

Wager, Harold W. T. 1900. "On the fertilization of Peronospora parasitica." Annals of botany 14, 263-279.

https://doi.org/10.1093/oxfordjournals.aob.a088777.

View This Item Online: https://www.biodiversitylibrary.org/item/238259

DOI: https://doi.org/10.1093/oxfordjournals.aob.a088777

Permalink: https://www.biodiversitylibrary.org/partpdf/318584

\section{Holding Institution}

Smithsonian Libraries

\section{Sponsored by}

Biodiversity Heritage Library

\section{Copyright \& Reuse}

Copyright Status: Not in copyright. The BHL knows of no copyright restrictions on this item.

This document was created from content at the Biodiversity Heritage Library, the world's largest open access digital library for biodiversity literature and archives. Visit BHL at https://www.biodiversitylibrary.org. 